\title{
An optimal designed experiment for the alkaline hydrolysis of feather keratin
}

\author{
Małgorzata Dąbrowska ${ }^{1} \cdot$ Agata Sommer $^{1} \cdot$ Izabela Sinkiewicz $^{1} \cdot$ Antoni Taraszkiewicz $^{1} \cdot$ Hanna Staroszczyk $^{1}$ (1)
}

Received: 30 July 2021 / Accepted: 16 November 2021 / Published online: 25 November 2021

(c) The Author(s) 2021

\begin{abstract}
Feathers, burdensome waste from the poultry industry, can be a cheap source of keratin, a protein with excellent physicochemical, biological, and mechanical properties. Acid and alkaline hydrolyses are usually adopted for isolation of keratin from its natural resources. This study aimed at assessing the statistically significant effect of input variables in the alkaline hydrolysis of keratin from chicken feathers on the process yield and on the molecular weight of peptides obtained. The effect of the volume ratio of $1 \mathrm{M} \mathrm{NaOH}$ to the feathers' mass, the hydrolysis time, and the shaking speed of the reaction mixture on the process yield were analyzed. The use of statistical analysis at the design step of experiment allowed reducing the trial number from 27 to 9 . Among the input variables analyzed, only the volume ratio of $1 \mathrm{M} \mathrm{NaOH}$ to the feathers' mass had a significant effect on the process yield, while none of them significantly affected the molecular weight of the peptides obtained. All hydrolysates were dominated by two peptides' fractions, with molecular weights of ca. 130 and $250 \mathrm{kDa}$, and mixture of many peptides of weight close to $10 \mathrm{kDa}$ and smaller. Alkaline hydrolysis of feather keratin yielded protein hydrolysates soluble over a wide $\mathrm{pH}$ range.
\end{abstract}

Keywords Feather waste $\cdot$ Keratin $\cdot$ Alkaline hydrolysis $\cdot$ Optimization

\section{Introduction}

Over the past 20 years, global plastic production has increased by around 260 million tons, ultimately reaching 359 million tons annually (PlasticsEurope 2020). Disposal of these materials is an increasing environmental challenge. During plastic waste decomposition, many toxic compounds migrate into the soil and groundwater, contaminating them and eventually killing the ecosystems that live there (Vethaak and Leslie 2016; Haider et al. 2019). When plastics are used for food packaging, the harmful compounds can be released into food, and hence, into consumer organisms, where they can bioaccumulate (Vethaak and Leslie 2016). Despite the negative aspects of using plastic, there are also many advantages of these materials, such as the resistance

Responsible Editor: Santiago V. Luis

Hanna Staroszczyk

hanna.staroszczyk@pg.edu.pl

1 Department of Food Chemistry, Technology and Biotechnology, Gdansk University of Technology, G. Narutowicza 11/12, 80-233 Gdańsk, Poland to mechanical damage, the low water vapor permeability, and the easy and cheap production. It is difficult to obtain a competitive biodegradable material with such good performance characteristics as synthetic materials.

The raw materials for the production of biodegradable materials can be proteins and polysaccharides, including protein- and polysaccharide-rich biomass resources (Schrooyen et al. 2000). For example, feathers from the poultry industry which account for ca. $10 \%$ of the total weight of a mature chicken are 90\% keratin (Cameron et al. 2003; Singh et al. 2017; Ciechanska et al. 2014). According to the periodic report published by the US Department of Agriculture, in the April 2021, over 100 million chickens were slaughtered annually, resulting in about 100 million tons of problematic feather waste (USDA, 2021). Thus, the use of waste biomass for the production of biodegradable materials is beneficial from both an economic and an environmental point of view (Singh et al. 2017; Ciechanska et al. 2014).

Keratin is a natural polymer with a structure and properties strikingly similar to synthetic polymers. Like the latter, keratin is a cross-linked macromolecule containing plasticizers and stabilizers (Hill et al. 2010). Due to a high number of hydrophobic amino acids and a highly cross-linked structure, 
keratin-based materials can not only be biodegradable but can also exhibit low water vapor permeability, low water absorption, and high resistance to mechanical damage, which has been difficult to achieve so far in the production of materials from raw materials of natural origin (Schrooyen et al. 2000; Dou et al. 2016; Reddy et al. 2013). Such keratin materials can contribute to the elimination of disadvantages of currently produced biodegradable protein-based materials (Schrooyen et al. 2000; Dou et al. 2016; Reddy et al. 2013), and to lower the use of synthetic polymeric materials and, consequently, to reduce the amount of problematic nonbiodegradable waste.

Keratin belongs to a heterogenous group of hydrophilic proteins insoluble in neither polar nor non-polar solvents, which are made in vertebral epithelial cells, forming animal fibers. Keratin products are durable and resistant to both physicochemical, biological, and mechanical external factors. These unique properties are related to the high content of cysteine residues, a sulfur amino acid, which allows the formation of intra- and intermolecular disulfide bridges between amino acids located in two different peptide chains, giving the keratin materials a hard and cross-linked structure (Cameron et al. 2003; Singh et al. 2017; Wang et al. 2016a). Feather keratin, with a molecular weight of ca. $10 \mathrm{kDa}$, consisting of $70-75 \% \alpha$-helix and $25-30 \% \beta$-sheet structure, is classified as $\beta$-keratins characterized by a higher sulfur content than keratin from other sources due to a large proportion of cysteine residues in their primary sequences (Cameron et al. 2003; Singh et al. 2017; Ciechanska et al. 2014; Schrooyen et al. 2001). This increases the frequency of cross-linking keratin via disulfide linkages, thereby enhancing the hardness, toughness, and strength of the feather structure (Cameron et al. 2003; Singh et al. 2017; Wang et al. 2016b).

Due to a high content of hydrophobic amino acids, a large number of intermolecular disulfide bridges, and a densely packed structure, keratin raw materials are insoluble in traditional protein solvents. However, the key aspect of keratin isolation is to bring it into the dissolved form (Singh et al. 2017; Schrooyen et al. 2001). Redox reactions and hydrolysis with both acid and alkaline reagents belong to the main chemical methods of keratin dissolution (Chooi Wei Cheong et al. 2018; Hill et al. 2010; Kurbanoglu and Kurbanoglu 2007; Vineis et al. 2021). The reduction method with the use of 2 mercaptoethanol and urea allows for a high degree of keratin isolation from the raw materials, while limiting hydrolysis degree of peptide bonds. However, reducing reagents are highly toxic to the environment and human health, and they are too expensive to be used on a technical scale (Schrooyen et al. 2001; Nakamura et al. 2002). The properties of keratin hydrolysates depend on the $\mathrm{pH}$, temperature, and reaction time (Coward-Kelly et al. 2006a, 2006b). The use of acid hydrolysis allows to a high protein extraction yield, but can result in the strong hydrolysis of peptide bond which lead to high protein fragmentation and loss of some amino acids such as tryptophan, methionine, and histidine (Liu et al. 1989). Although disulfide bridges and peptide bonds are also broken during alkaline hydrolysis, it can result in a mixture of all amino acids present in the native protein (Singh et al. 2017; Coward-Kelly et al. 2006a, 2006b; Gousterova et al. 2005; Nagai and Nishikawa 1970; Song et al. 2013; Tsuda and Nomura 2014). An increased reaction temperature and a high concentration of alkali used lead to an increased protein yield but cause its strong fragmentation, bringing about low-molecular-weight protein fractions. Unfortunately, such proteins do not show film-forming properties, unlike e.g. collagen and gelatin characterized by a high molecular weight, ca. 150-300 kDa (Abraham et al. 2008; Gómez-Guillén et al. 2009). Therefore, it is important to select conditions of alkaline hydrolysis that will yield the high-molecular-weight protein fractions, capable of film formation (Singh et al. 2017).

The aim of the study was to assess the statistically significant effect of input variables in the alkaline hydrolysis of keratin from white chicken feathers, carried out at room temperature using sodium hydroxide, on the process yield, molecular weight of the peptides obtained. The effects of the volume ratio of $1 \mathrm{M} \mathrm{NaOH}$ to the feather mass, the hydrolysis time, and the shaking speed of the reaction mixture were statistically analyzed. The pretreatment process of feathers and the purification process of hydrolysates obtained were carried out according to typical methods reported by other authors (Schrooyen et al. 2000; Singh et al. 2017; Nakamura et al. 2002; Sinkiewicz et al. 2017); however, with some modifications. Namely, the processes of degreasing feathers with organic solvents and grinding feathers as well as dialysis and freeze-drying of hydrolysates obtained were omitted. Skipping these processes allowed eliminating the use of environmentally harmful reagents, to shorten the processing time, and to reduce energy consumption. All these steps together have contributed to making the process more environmentally friendly.

To the best our knowledge, no research has been conducted so far on a statistical analysis of the process conditions of alkaline hydrolysis of keratin from white chicken feathers. In our opinion, this allows for a precise optimization of the method in the context of obtaining protein fractions useful for the formation of biodegradable films.

\section{Materials and methods}

\section{Materials}

White chicken feathers were supplied by a local poultry slaughterhouse (Drobful, Poland). $\mathrm{NaOH}$ (POCH, Poland) 
Fig. 1 Black box model for keratin hydrolysis
Input variables controlled but not designed

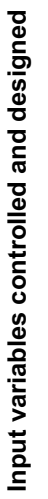

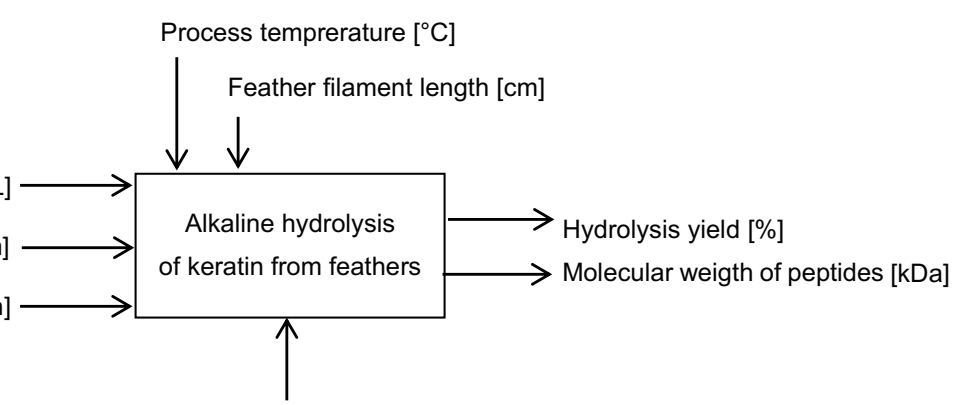

Variable quality of raw material

Input variables neither controlled nor designed

was used to carry out the hydrolysis. DTT and Coomassie brilliant blue R-250 (Fluka, USA), SDS (Merck, Germany), $30 \%$ solution of acyrlamide/bis-acrylamide, ammonium persulfate, bromophenol solution, glycine, hydrochloric acid, TEMED, and trizma base (Sigma-Aldrich, USA), acetic acid, glycerol and methanol (Chempur, Poland), ammonium perfulfate, and prestained protein ladder PageRuler Plus (Thermo scientific, USA) were applied for determination of protein molecular weight. Sulfuric acid and Tashiro's indicator (POCH, Poland), selenium catalyst (Chempur, Poland), boric acid, and hydrochloric acid (Stanlab, Poland) were used to determine the protein content by the Kjeldahl method.

\section{Pretreatment of feathers}

To increase the hydrolysis yield, the pretreatment of feathers was performed by removing impurities and lipid compounds that naturally cover the feathers. This step has been simplified compared to the previous one (Sinkiewicz et al. 2017). Briefly, whole feathers were washed in warm water with detergent until impurities and lipids were removed, dried at $50^{\circ} \mathrm{C}$ for $24 \mathrm{~h}$, and then cut into 2-3 $\mathrm{cm}$ long filaments.

\section{Alkaline hydrolysis}

The hydrolysis process was carried out at room temperature to prevent strong hydrolysis of the peptide bonds and to obtain the high-molecular-weight protein fractions (Mokrejs et al. 2011). The pure defatted feathers were shaken (Thermo Forma 420 Orbital Shaker, Thermo Scientific, USA) at 150, 175, or $200 \mathrm{rpm}$ for 24,16 , or $32 \mathrm{~h}$, respectively, with distilled water in a ratio of 1:10 to the mass of feathers during the first hour, and next, $1 \mathrm{M} \mathrm{NaOH}$ was added, and shaking was continued. The hydrolysates obtained were centrifuged at $5000 \mathrm{rpm}$ for 15 min (MPW-350R Centrifuge, MPW Med. Instruments, Poland) to get rid of insoluble feather residues and filtered. The filtrate hydrolysates were neutralized with $1 \mathrm{M} \mathrm{HCl}$ and used for analyses.

\section{Determination of keratin hydrolysis yield}

The total nitrogen content in the dry matter of pure feathers and in the hydrolysates obtained was determined by the Kjeldahl method and then converted into the total protein content by using a literature conversion factor of 5.71 (AOAC 1990; Grazziotin et al. 2006). The hydrolysis yield was calculated based on the results of the total protein content in feathers and in hydrolysates:
Table 1 Permutated Latin square with three levels of variations filled with conditions of alkaline hydrolysis process

\begin{tabular}{|c|c|c|c|c|c|c|c|c|c|}
\hline \multicolumn{2}{|c|}{$\begin{array}{l}\text { Levels of the variability } \\
\text { for the input variables }\end{array}$} & \multicolumn{3}{|c|}{ Variable $x_{1}$} & & & \multicolumn{3}{|c|}{$\begin{array}{l}\text { Volume of } 1 \mathrm{M} \mathrm{NaOH} \\
{[\mathrm{mL}]}\end{array}$} \\
\hline & & -1 & 0 & 1 & & & 75 & 150 & 225 \\
\hline \multirow[t]{3}{*}{ Variable $x_{2}$} & -1 & A & $\mathrm{C}$ & B & \multirow{3}{*}{$\begin{array}{l}\text { Hydrolysis } \\
\text { time }[\mathrm{h}]\end{array}$} & 16 & 150 & 200 & 175 \\
\hline & 0 & $\mathrm{C}$ & B & A & & 24 & 200 & 175 & 150 \\
\hline & 1 & B & A & $\mathrm{C}$ & & 32 & 175 & 150 & 200 \\
\hline
\end{tabular}

$-1,0,1$-three levels of the variability for the input variable $x_{1}$, volume of $1 \mathrm{M} \mathrm{NaOH}[\mathrm{mL}]$, and $\mathrm{x}_{2}$, hydrolysis time $[\mathrm{h}]$

$\mathrm{A}, \mathrm{B}, \mathrm{C}$-three levels of the variability for the input variable $x_{3}$, shaking speed of the reaction mixture $[\mathrm{rpm}]$ 
Table 2 Effect of input variables on keratin hydrolysis yield

\begin{tabular}{llllll}
\hline $\begin{array}{l}\text { Hydrolysate } \\
\text { no. }\end{array}$ & $\begin{array}{l}1 \mathrm{M} \mathrm{NaOH} \\
{[\mathrm{mL}]}\end{array}$ & $\begin{array}{l}\text { Hydrolysis } \\
\text { time }[\mathrm{h}]\end{array}$ & $\begin{array}{l}\text { Shaking speed } \\
{[\mathrm{rpm}]}\end{array}$ & $\begin{array}{l}\text { Total protein content } \\
{[\mathrm{g} / 100 \mathrm{~mL}]}\end{array}$ & Hydrolysis yield [\%] \\
\hline 1 & 75 & 16 & 150 & $2.49 \pm 0.19$ & $11.33 \pm 0.87$ \\
2 & 150 & 16 & 200 & $3.33 \pm 0.07$ & $15.17 \pm 0.33$ \\
3 & 225 & 16 & 175 & $5.24 \pm 0.54$ & $23.84 \pm 2.44$ \\
4 & 75 & 24 & 200 & $2.52 \pm 0.16$ & $11.45 \pm 0.74$ \\
5 & 150 & 24 & 175 & $3.49 \pm 0.20$ & $15.90 \pm 0.90$ \\
6 & 225 & 24 & 150 & $8.12 \pm 0.08$ & $36.96 \pm 0.36$ \\
7 & 75 & 32 & 175 & $2.85 \pm 0.15$ & $12.96 \pm 0.66$ \\
8 & 150 & 32 & 150 & $5.06 \pm 0.07$ & $23.04 \pm 0.34$ \\
9 & 225 & 32 & 200 & $9.02 \pm 0.32$ & $41.05 \pm 1.46$ \\
\hline
\end{tabular}

$Y[\%]=\frac{\text { total protein content in hydrolysates }[g]}{\text { total protein content in feathers }[g]} \cdot 100 \%$

\section{Determination of solubility properties of hydrolysates}

The possibility of using keratin hydrolysates in the film preparation depend not only on the hydrolysis yield, but also on their functional properties, such as solubility at different $\mathrm{pH}$. To determine the solubility of hydrolysates obtained, the $\mathrm{pH}$ of each sample of hydrolysate suspension was adjusted to 2-7 by using $1 \mathrm{M} \mathrm{HCl}$, and the resulting turbidity was measured using a spectrophotometer (Spectroquant ${ }^{\circledR}$ Pharo 300, Merck, Germany) at $280 \mathrm{~nm}$. The measurements were taken in triplicate, and results, expressed as mean values, were presented in the form of a plot of absorbance versus $\mathrm{pH}$. Then, insoluble protein was precipitated from hydrolysate (the highest turbidity) with $1 \mathrm{M} \mathrm{HCl}$, filtered, dried, and weighed. The soluble protein content in the hydrolysates was determined at $\mathrm{g} / 100 \mathrm{~mL}$ of hydrolysate.

\section{Determination of the molecular weight of peptides by sodium dodecyl sulfate-polyacrylamide gel electrophoresis (SDS-PAGE)}

To determine the molecular weight of the peptides contained in the keratin hydrolysates, SDS-PAGE was performed according to the method of Laemmli (1970). The samples of $40 \mathrm{mg}$ of dialyzed and then freeze-dried hydrolysate were mixed with $1 \mathrm{~mL}$ water, loaded onto each lane for comparison, resolved on a $12 \%$ separation gel, and stained with $0.25 \%(w / v)$ Coomassie brilliant blue. A marker having a molecular weight of 10-250 kDa was used as a standard.

\section{Process optimization using designed experiment}

The purpose of using the statistical analysis was to select the parameters of key importance in the process of alkaline hydrolysis. The hydrolysis process was designed using a black box model (Fig. 1). Three input variables for this process were selected, which were both controlled and designed: (i) the ratio of the $1 \mathrm{M} \mathrm{NaOH}$ volume to the feathers mass [v/w], (ii) the hydrolysis time [h], and (iii) the shaking speed of the reaction mixture [rpm]. The ratio of the volume of $1 \mathrm{M} \mathrm{NaOH}$ to the mass of feathers was $3: 1,6: 1$, and $9: 1$ [v/w], corresponding to 75,150 , and $225 \mathrm{~mL}$ of $1 \mathrm{M} \mathrm{NaOH}$, respectively. The hydrolysis time was 16,24 , and $32 \mathrm{~h}$, and the shaking speed of the reaction mixture was 150,175 , and $200 \mathrm{rpm}$.

Performing the hydrolysis for three different volumes of $1 \mathrm{M} \mathrm{NaOH}$, three different hydrolysis times, and three different shaking speeds would require 27 combinations of these parameters for only one repetition. To determine which process conditions has a significant effect on the hydrolysis yield and the resulting protein size, the method of statistically significant effect was applied at the design step. Latin square was used for this purpose. This method reduced the numbers of trials needed to be performed from 27 to 9, thus, reducing the cost and time of the study by three times. The Latin square method meets all the conditions of the research model, such as randomization, number of input variables, and levels of variation, and allows easy and quick application without the need for specialized software (de Winter and Dodou 2017; Korzyński 2013).

The left side of Table 1 shows a general scheme of the randomized Latin square. The input variables were randomly recorded at three levels of variation $(n=3)$, from -1 to 1 for variables $x_{1}$ and $x_{2}$, in columns and rows, respectively, and from $\mathrm{A}$ to $\mathrm{C}$ for variable $x_{3}$, located inside the square. The right side of Table 1 presents the Latin square for the alkaline hydrolysis, filled with the process conditions, that was created based on the general scheme. After determining the hydrolysis yield and the molecular weight of peptides obtained, the results will be inserted into the Latin square, and for each of the input variables tested, the Fisher-Snedecor statistics, called the empirical F value, will be calculated (de Winter and Dodou 2017; Korzyński 2013). Results of the statistical 


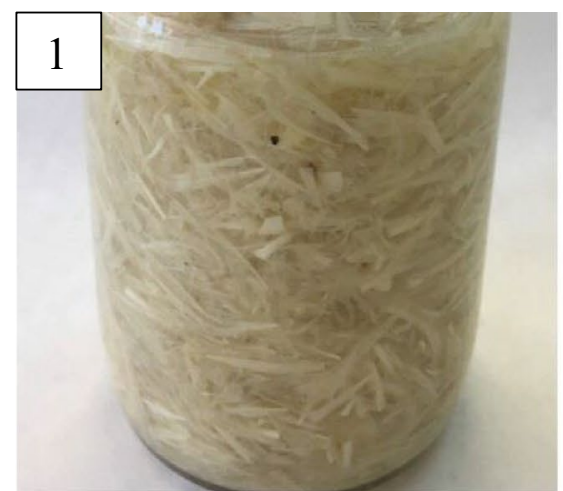

$16 \mathrm{~h}, 75 \mathrm{~mL} \mathrm{NaOH}, 150 \mathrm{rpm}$

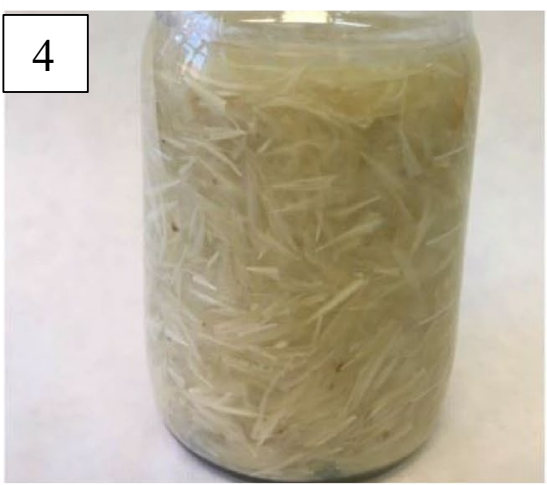

24 h, $75 \mathrm{~mL} \mathrm{NaOH}, 200 \mathrm{rpm}$

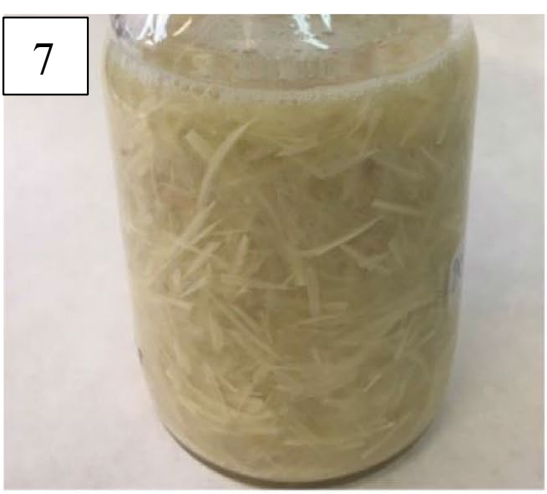

32 h, $75 \mathrm{~mL} \mathrm{NaOH}, 175 \mathrm{rpm}$

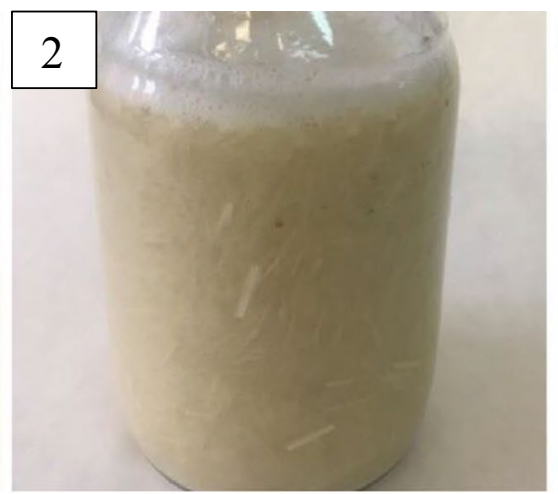

16 h, $150 \mathrm{~mL} \mathrm{NaOH}, 200 \mathrm{rpm}$

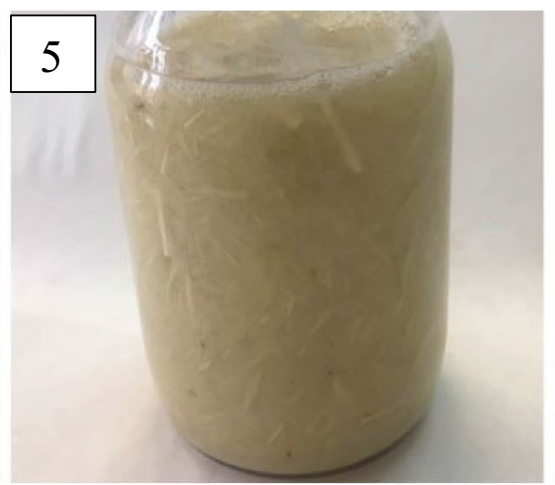

$24 \mathrm{~h}, 150 \mathrm{~mL} \mathrm{NaOH}, 175 \mathrm{rpm}$

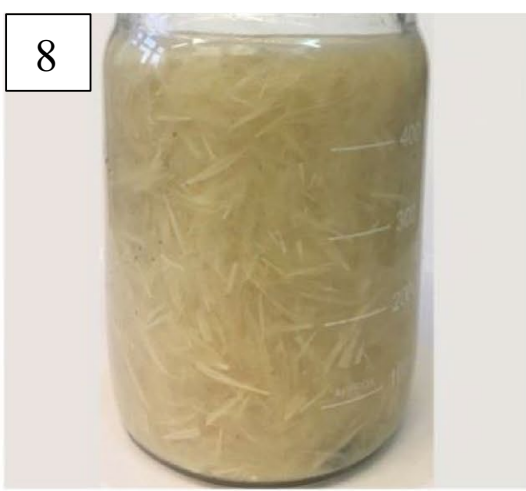

$32 \mathrm{~h}, 150 \mathrm{~mL} \mathrm{NaOH}, 150 \mathrm{rpm}$

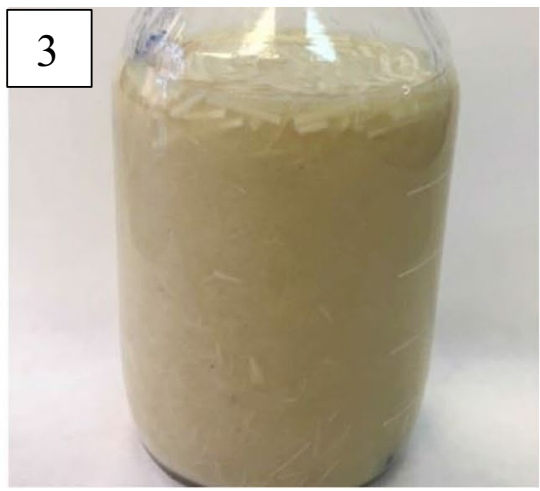

16 h, $225 \mathrm{~mL} \mathrm{NaOH}, 175$ rpm

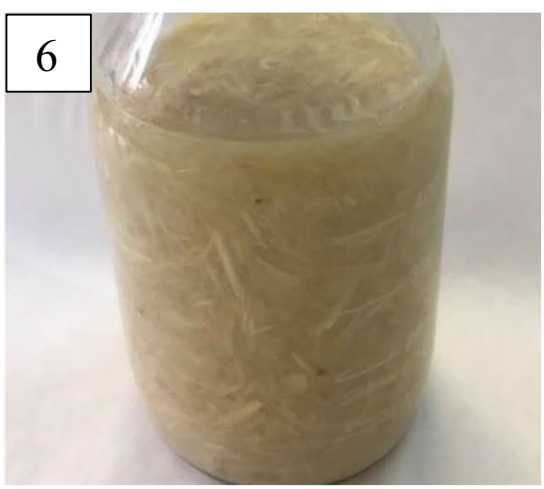

$24 \mathrm{~h}, 225 \mathrm{~mL} \mathrm{NaOH}, 150 \mathrm{rpm}$

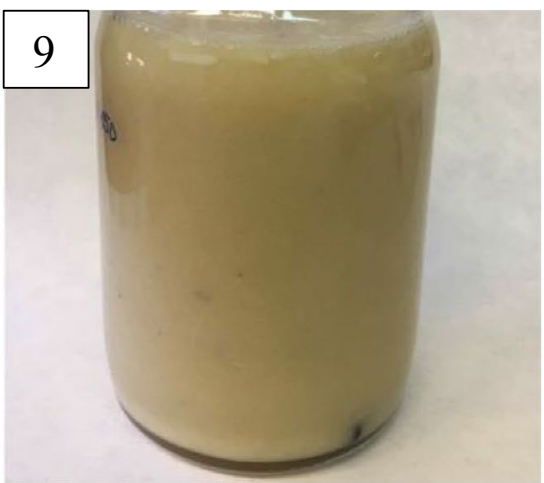

32 h, $225 \mathrm{~mL} \mathrm{NaOH}, 200$ rpm

Fig. 2 Photos of reaction mixtures after hydrolysis (please, compare the captions under the drawings with the names of columns 1-4 in Table 2)

test will answer the question of which input variables in the alkaline hydrolysis process of keratin from feathers had a significant effect on the keratin yield.

\section{Results and discussion}

\section{Effect of input variables on keratin hydrolysis yield}

The average total protein content in the dry matter of feathers was $87.9 \pm 0.58 \%$ and was similar to that reported by other authors. According to Kumar et al. (2012), it is more than $85 \%$, and according to Saravanan and Dhurai (2012), it is $90 \%$.

Table 3 The randomized Latin square filled with the results of hydrolysis yield

\begin{tabular}{lllll}
\hline Levels of input variability & & \multicolumn{3}{c}{ Volume of $1 \mathrm{M} \mathrm{NaOH}[\mathrm{mL}]$} \\
\cline { 3 - 5 } & & 75 & 150 & 225 \\
\hline Hydrolysis time [h] & 16 & 11.33 & 15.17 & 23.84 \\
& 24 & 11.45 & 15.90 & 36.96 \\
& 32 & 12.96 & 23.04 & 41.05 \\
\hline
\end{tabular}



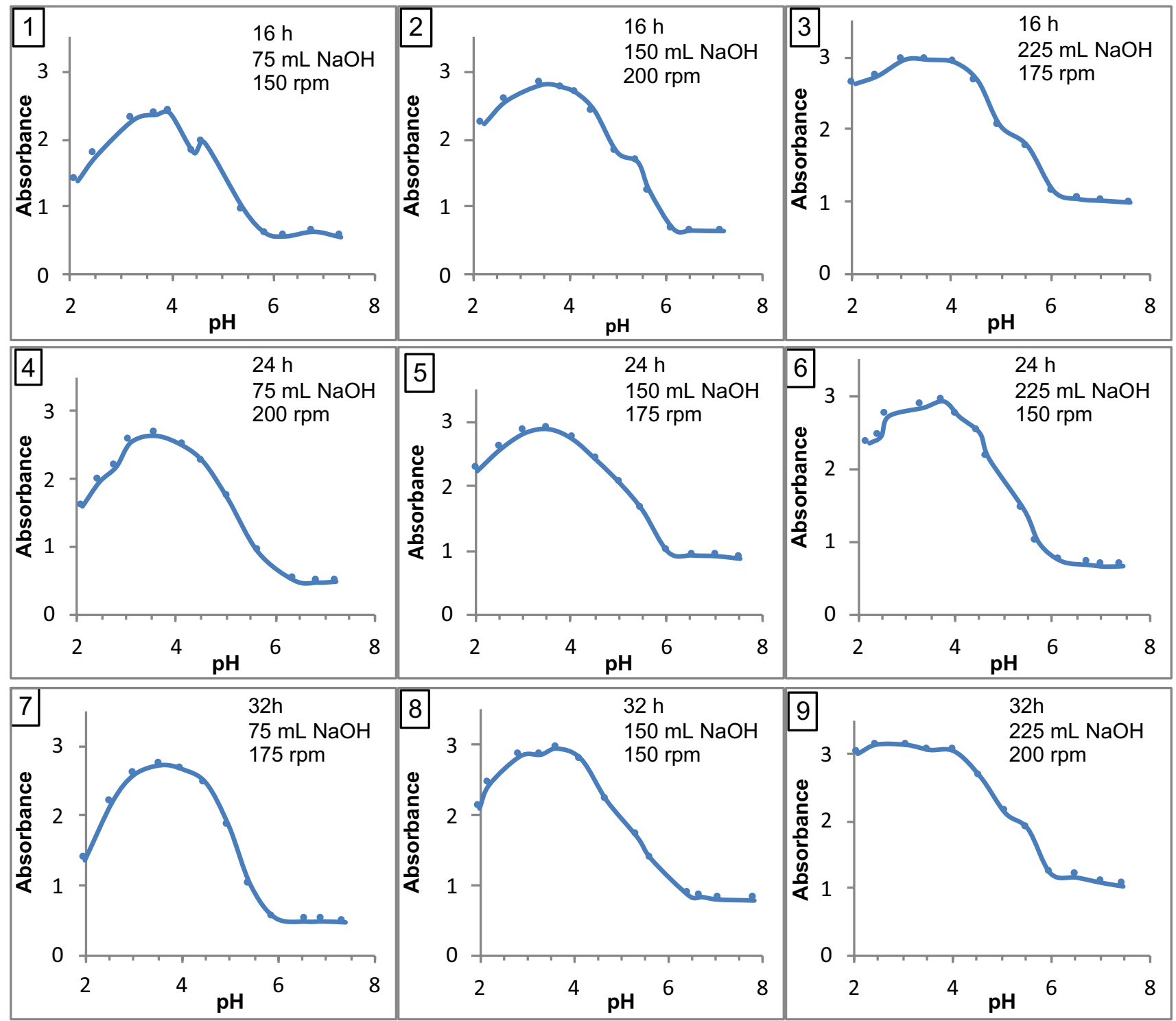

Fig. 3 The plots of absorbance versus $\mathrm{pH}$ indicating solubility properties of hydrolysates

The highest yield of keratin isolation carried out at room temperature was achieved when the volume of $1 \mathrm{M} \mathrm{NaOH}$ was the highest and was $225 \mathrm{~mL}$, regardless of the other process parameters (Table 2). This yield was ca. 24, 37, and $41 \%$ after 16, 24, and $32 \mathrm{~h}$ hydrolysis time, respectively. Figure 2 presents the photos of reaction mixtures taken before the filtration step. Undissolved feather residues were found in all trials, except for sample no. 9, in which the highest input variable parameters were used, i.e., volume of $1 \mathrm{M} \mathrm{NaOH}$, $225 \mathrm{~mL}$, the hydrolysis time, $32 \mathrm{~h}$, and shaking speed of the reaction mixture, $200 \mathrm{rpm}$. Taking into accounts the results of the hydrolysis yield (Table 2), it can be seen that the lower amount of undissolved residue (Fig. 2), the higher the hydrolysis yield was achieved. According to Nomura et al.
(2007), the yield of the feather hydrolysis process carried out at room temperature ranges from 30 to $70 \%$, depending on the process time and the alkali concentration used. The much higher hydrolysis yield realized by these authors was probably due to a 3-10 times higher ratio of $1 \mathrm{M} \mathrm{NaOH}$ volume to feather mass than that used in presented study. Our previous study revealed that by conducting the alkaline hydrolysis not at room temperature but at $70^{\circ} \mathrm{C}$, at the ratio of $1 \mathrm{M} \mathrm{NaOH}$ to feather mass of 10:1 [v/w] and for a period of $1 \mathrm{~h}$ and $15 \mathrm{~min}$, keratin can be obtained with yield of ca. 29\% (Sinkiewicz et al. 2017). Thus, the results presented in Table 2 indicate that by lowering the process temperature but running the process for a longer period of time, the higher process yield can be obtained. 
The results of hydrolysis yield were inserted into the relevant Latin square fields as shown in Table 3. The calculations of the significance of the effect of one input variable on the hydrolysis yield, namely the volume of the $1 \mathrm{M} \mathrm{NaOH}$, are presented below. The calculations for the two other input variables, the hydrolysis time and the shaking speed, were performed analogously.

To determine the empirical $F$ value, in the first step, the results from each of the three columns $\left(C_{1}, C_{2}, C_{3}\right)$, indicated the volume of $1 \mathrm{M} \mathrm{NaOH}$ used $(75 \mathrm{~mL}, 150 \mathrm{~mL}, 225 \mathrm{~mL})$, were summed:

$$
\begin{gathered}
C_{i}=\sum_{i=1}^{P} y_{i} \\
C_{1}=11.33+11.45+12.96=35.74 \\
C_{2}=15.17+15.90+23.04=54.11 \\
C_{3}=23.84+36.96+41.05=101.85
\end{gathered}
$$

In the second step, the sums of the results from the columns were squared and divided by numbers of levels of variability $(n=3)$, obtaining the arithmetic mean of the squares of these quantities $\left(C^{2}\right)$ :

$$
\begin{gathered}
C^{2}=\frac{1}{n} \sum_{i=1}^{P} C_{i}^{2} \\
C^{2}=\frac{35.74+54.11+101.85}{3}=4859.55
\end{gathered}
$$

Next, the square of arithmetic average of the sum over all experimental results $(\Delta y)$, for $n=3$ was calculated:

$$
\Delta y=\frac{1}{n^{2}}\left(\sum_{i=1}^{p^{2}} y_{i}\right)^{2}
$$

$\Delta y=\frac{(11.33+15.17+23.84+11.45+15.90+36.96+12.96+23.04+41.05)^{2}}{9}=4083.21$

The $C^{2}$ value was decreased by $\Delta y$ value, obtaining the sum of squares for the columns $\left(S_{\mathrm{C}}\right)$. In the next step, the $\Delta y$ value was subtracted from the sum of squares of all results from the Latin square, obtaining the overall sum of squares of all experimental results $(S)$ :

$$
\begin{gathered}
S_{C}=C^{2}-\Delta y \\
S_{C}=4859.55-4083.21=776.34
\end{gathered}
$$

$$
\begin{gathered}
S_{E}=S-S_{R}-S_{C}-S_{L} \\
S_{E}=977.49-118.99-776.34-64.95=17.21
\end{gathered}
$$

The degrees of freedom $f$ for the columns $\left(f_{\mathrm{c}}\right)$, the rows $\left(f_{\mathrm{R}}\right)$, and the letters $\left(f_{\mathrm{L}}\right)$ and the degrees of freedom for the error $\left(f_{\mathrm{E}}\right)$ were:

$f_{C}=n-1$

$f_{R}=n-1$

$f_{L}=n-1$

$f_{E}=(n-1)(n-2)$

$f_{R}=f_{C}=f_{L}=3-1=2$

$f_{E}=(3-1)(3-2)=2$

In the next step, the variance value for columns $\left(S_{\mathrm{C}}{ }^{2}\right)$ and error $\left({S_{\mathrm{E}}}^{2}\right)$ was calculated by dividing the sum of their square by the number of their degrees of freedom $\left(f_{\mathrm{C}}\right.$ or $\left.f_{\mathrm{E}}\right)$.

$S_{C}^{2}=\frac{S_{C}}{f_{C}}$

$S_{C}^{2}=\frac{17.21}{2}=8.6$

$S_{E}^{2}=\frac{S_{E}}{f_{17.21}}$

$S_{E}^{2}=\frac{f_{E}}{2}=8.60$

To calculate the variance quotients, denoting the empirical $F$ values, the variance for the columns $\left(S_{\mathrm{C}}^{2}\right)$ was divided by the variance for the error $\left({S_{\mathrm{E}}}^{2}\right)$. This calculated empirical $F$ value was then compared with a critical $F_{\text {cr }}$ value of Fisher-Sendecor distribution for a significance level of $\alpha=0.05$ and the number of degrees of freedom $f_{1}=f_{\mathrm{C}}=f_{\mathrm{R}}$ $=f_{\mathrm{L}}$ and $f_{2}=f_{\mathrm{E}}$ as equal 19 .

$$
\begin{gathered}
F_{C}=\frac{S_{C}{ }^{2}}{S_{E}^{2}} \\
F_{C}=\frac{388.17}{8.6}=45.11
\end{gathered}
$$

$S=\left(11.33^{2}+15.17^{2}+23.84^{2}+11.45^{2}+15.90^{2}+36.96^{2}+12.96^{2}+23.04^{2}+41.05^{2}\right)-4081.23=977.49$

$$
S=\sum_{i=1}^{p^{2}} y_{i}^{2}-\Delta y
$$

To calculate the sum of squares for the experimental error $\left(S_{\mathrm{E}}\right)$, the $S_{\mathrm{C}}$ values as well as $S_{\mathrm{R}}$ and $S_{\mathrm{L}}$ values, representing the sum of squares for the rows and for the letters, respectively, were subtracted from the value of $S$ :

$$
\begin{gathered}
F_{c r}=F_{\left(\alpha ; f_{1} ; f_{2}\right)} \\
F_{c r}=F_{(0,05 ; 2 ; 2)}=19 \\
F_{C}(45.11) \geq F_{c r}(19)
\end{gathered}
$$




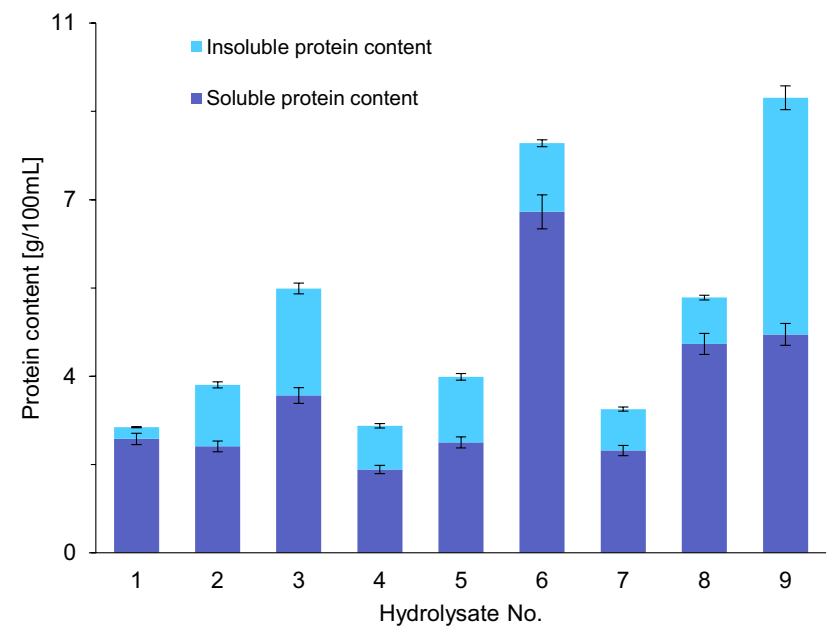

Fig. 4 The content of soluble and insoluble proteins in the hydrolysates obtained

If the empirical $F$ value was $\geq F_{\text {cr }}$, then the effect of the input variable on the outcome factor variable will be considered significant with $95 \%$ confidence level. The $F_{\mathrm{C}}$ was equal 45.11 so the effect of the volume of $1 \mathrm{M} \mathrm{NaOH}$ solution on the hydrolysis yield is considered significant.

The results of the other empirical $F$ value, $F_{\mathrm{R}}$ and $F_{\mathrm{L}}$ for each input variable, were sequential: 6.91 for the hydrolysis time, 3.77 for the shaking speed. These results are lower than $F_{\text {cr }}=19$ thus should be considered as insignificant on the hydrolysis keratin yield in the ranges tested.

\section{Solubility properties of hydrolysates}

The results presented in Figure 3 show that the least soluble proteins were in a solution of $\mathrm{pH} 3.4-4.0$, i.e., the $\mathrm{pH}$ close to the isoelectric point ( $\mathrm{pI}$ ) of keratin. According to Bragulla and Homberger (2009), pI of reduced keratin determined by the electrophoretic method is in the range of 4.9-5.4. The differences in the $\mathrm{pI}$ values obtained were probably due to the use of a different method of keratin isolation and the presence in the hydrolysate obtained of a mixture of polypeptides with different molecular weight and different $\mathrm{pI}$. The method of $\mathrm{pI}$ determination could also have influenced the results. In the presented study, peptides were precipitated from a strongly alkaline solution using $\mathrm{HCl}$, which led to the high salinity of the mixture. Under condition of high $\mathrm{NaCl}$ content, the proteins are deprived of their water envelope. Then, the strength of intermolecular hydrophobic interactions increases, which leads to the precipitation of proteins from the solution and, consequently, to a decrease in their solubility, and thus a shift of the pI towards lower values.

The content of insoluble protein $[\mathrm{g} / 100 \mathrm{~mL}]$ in the hydrolysates obtained, founded after its precipitation and drying, was compared with the content of total protein [g/100mL] (Fig. 4). These results clearly prove that in all hydrolysates the soluble protein fraction was predominant.

\section{Determination of the molecular weight of peptides by SDS-PAGE}

Electrophoretic profiles of hydrolysates obtained revealed subtle differences. While two peptide fractions of 130 and 250
Fig. 5 SDS-PAGE profiles of hydrolysates (1-9) with the protein ladder on lane 0 . The numbers of hydrolysates are in accordance with Table 2

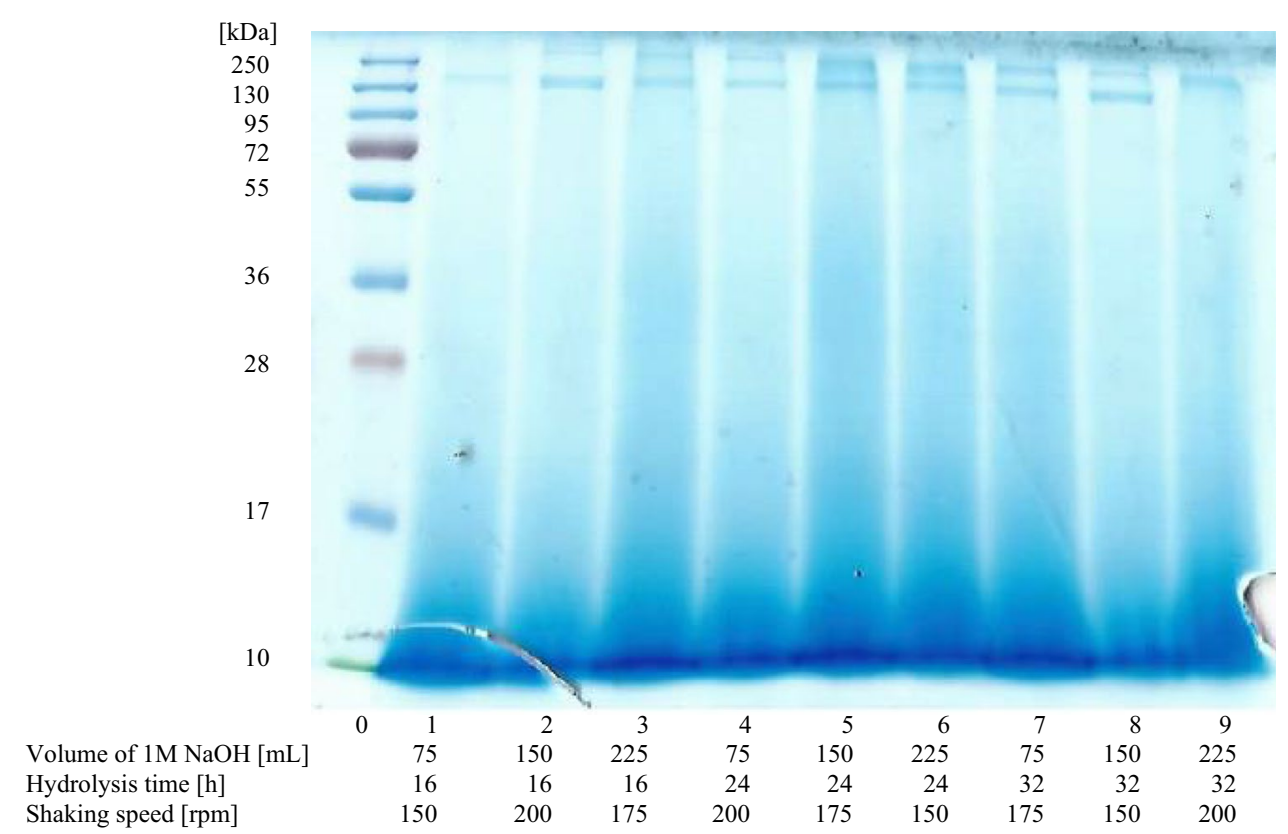


$\mathrm{kDa}$ molecular weights were dominated in all hydrolysates, in that of No. 9, obtained under the most extreme conditions (the volume of $1 \mathrm{M} \mathrm{NaOH}, 225 \mathrm{~mL}$, the hydrolysis time, $32 \mathrm{~h}$, the shaking speed of the reaction mixture, $200 \mathrm{rpm}$ ), the peptide fraction of $130 \mathrm{kDa}$ was not observed (Fig. 5). Moreover, the profiles of all hydrolysates indicated the presence of peptides with the molecular weight lower than $10 \mathrm{kDa}$. According to Wang et al. (2016b), the molecular weight of $\alpha$-keratin ranges in size from 40 to $68 \mathrm{kDa}$, and that of $\beta$-keratin from 10 to $22 \mathrm{kDa}$. Thus, presence of peptide fractions of much higher molecular weights in the hydrolysates obtained can indicate an incomplete rupture of peptide bonds during hydrolysis process. However, the results of other authors indicate that alkaline hydrolysis of keratin leads to peptides of various sizes, depending on the process conditions. Nomura et al. (2007) using alkaline hydrolysis with $1 \mathrm{M} \mathrm{NaOH}$ received peptides of 8-13 kDa, but at the volume ratio of alkali to the feathers mass 3-10 times higher than that used in the presented work. Song et al. (2013) obtained fractions with a molecular weight of $5.8 \mathrm{kDa}$ after alkaline hydrolysis of feather keratin. These differences in molecular weight can be explained by the extraction conditions, such as hydrolysis time, volume, and concentration of alkaline and shredding treatments such as blending and homogenization of feathers or reaction mixture, which were different in each study. The results of SDS-PAGE analysis indicated also different concentrations of peptides present in each of the hydrolysates as the intensity of individual bands in their profiles varied (Fig. 5). The greatest intensity of the bands was observed in the samples whose hydrolysis proceeded with the highest volume of $1 \mathrm{M} \mathrm{NaOH}$ (lane 3,6, and 9), regardless of other process conditions, such as hydrolysis time and shaking speed of the reaction mixture.

\section{Conclusions}

The randomized Latin square statistical program allowed to assess the significance of the influence of three input variables, with three levels of variability, on the final result of alkaline hydrolysis of soluble keratin from chicken feathers, limiting the number of trials from 27 to 9 necessary to perform, which reduced research cost and time. The use of the Latin square has made it possible to determine which variables in the process of alkaline hydrolysis of feather keratin had a significant impact on the protein yield. The hydrolysis yield was significantly influenced by the volume ratio of $1 \mathrm{M} \mathrm{NaOH}$ to the mass of feathers, and the influence of hydrolysis time and shaking speed of the reaction mixture in the tested ranges on this yield were insignificant. Alkaline hydrolysis of feather keratin allowed obtaining a protein hydrolysate soluble in the wide $\mathrm{pH}$ range. SDS-PAGE electrophoreogram analysis showed that the conditions of alkaline hydrolysis in the tested ranges had little effect on the size of the keratin peptides obtained.
Data availability The datasets used and analyzed during the current study are available from the corresponding author on reasonable request.

Author contribution Małgorzata Dąbrowska: data curation, formal analysis, investigation, methodology, visualization, writing-original draft preparation

Agata Sommer: conceptualization, data curation, formal analysis, methodology, resources, supervision, validation, visualization, writing-review and editing

Izabela Sinkiewicz: investigation

Antoni Taraszkiewicz: investigation

Hanna Staroszczyk: project administration, supervision, writingreview and editing

All authors have read and agreed to the published version of the manuscript.

\section{Declarations}

Ethics approval and consent to participate Not applicable.

Consent for publication Not applicable.

Competing interests The authors declare no competing interests.

Open Access This article is licensed under a Creative Commons Attribution 4.0 International License, which permits use, sharing, adaptation, distribution and reproduction in any medium or format, as long as you give appropriate credit to the original author(s) and the source, provide a link to the Creative Commons licence, and indicate if changes were made. The images or other third party material in this article are included in the article's Creative Commons licence, unless indicated otherwise in a credit line to the material. If material is not included in the article's Creative Commons licence and your intended use is not permitted by statutory regulation or exceeds the permitted use, you will need to obtain permission directly from the copyright holder. To view a copy of this licence, visit http://creativecommons.org/licenses/by/4.0/.

\section{References}

Abraham LC, Zuena E, Perez-Ramirez B, Kaplan DL (2008) Guide to collagen characterization for biomaterial studies. J Bomed Mater Res B Appl Biomater 87B(1):264-285. https://doi.org/10.1002/ jbm.b.31078

AOAC (1990). In: Helrich K (ed) Official methods of analysis, 15th edn. Virginia

Bragulla HH, Homberger DG (2009) Structure and functions of keratin proteins in simple, stratified, keratinized and cornified epithelia. J Anat 214:516-559. https://doi.org/10.1111/j.1469-7580.2009. 01066.x

Cameron GJ, Wess TJ, Bosner RHC (2003) Young's modulus varies with differential orientation of keratin in feathers. J Struct Biol 143:118-123. https://doi.org/10.1016/s1047-8477(03)00142-4

Cheong CW, Lee YS, Ahmad SA, Ooi PT, Phang LY (2018) Chicken feather valorization by thermal alkaline pretreatment followed by enzymatic hydrolysis for protein-rich hydrolysate production. Waste Manag 79:658-666. https://doi.org/10.1016/j.wasman. 2018.08.029

Ciechanska D, Wietecha J, Kucharska M, Wrzeoeniewska-Tosik K, Kopania E (2014) Biomass as a source of functional polymeric materials. Polimery/Polymers 59:383-392. https://doi.org/10. 14314/polimery.2014.383 
Coward-Kelly G, Chang VS, Agbogbo FK, Holtzapple MT (2006a) Lime treatment of keratinous materials for the generation of highly digestible animal feed: 1 . Chicken feathers. Bioresour Technol 97:1337-1343. https://doi.org/10.1016/j.biortech.2005. 05.021

Coward-Kelly G, Agbogbo FK, Holtzapple MT (2006b) Lime treatment of keratinous materials for the generation of highly digestible animal feed: 2. Animal hair. Bioresour Technol 97:1344-1352. https://doi.org/10.1016/j.biortech.2005.05.017

Dou Y, Zhang B, He M, Yin G, Cui Y (2016) The structure, tensile properties and water resistance of hydrolyzed feather keratinbased bioplastics. Chinese J Chem Eng 24:415-420. https://doi. org/10.1016/j.cjche.2015.11.007

Gómez-Guillén MC, Pérez-Mateos M, Gómez-Estaca J, López-Caballero E, Giménez B, Montero P (2009) Fish gelatin: a renewable material for developing active biodegradable films. Trends Food Sci Tech 20:3-16. https://doi.org/10.1016/j.tifs.2008.10.002

Gousterova A, Braikova D, Goshev I, Christov P, Tishinov K, VasilevaTonkova E, Haertlé T, Nedkov P (2005) Degradation of keratin and collagen containing wastes by newly isolated thermoactinomycetes or by alkaline hydrolysis. Lett Appl Microbiol 40:335340. https://doi.org/10.1111/j.1472-765X.2005.01692.x

Grazziotin A, Pimentel FA, De Jong EV, Brandelli A (2006) Nutritional improvement of feather protein by treatment with microbial keratinase. Anim Feed Sci Technol 126:135-144. https://doi.org/ 10.1016/j.anifeedsci.2005.06.002

Haider TP, Völker C, Kramm J, Landfester K, Wurm FR (2019) Plastics of the future? The impact of biodegradable polymers on the environment and on society. Angew Chemie - Int Ed 58:50-62. https://doi.org/10.1002/anie.201805766

Hill P, Brantley H, Van Dyke M (2010) Some properties of keratin biomaterials: kerateines. Biomaterials 31:585-593. https://doi. org/10.1016/j.biomaterials.2009.09.076

Korzyński M (2013) Study on the significance of impact. In: Korzynski M (ed) Methodology an experiment: Planning, implementation and statistical processing of results of technological experiments. WNT, Warsaw, pp 122-160

Kumar DJM, Priya P, Balasundari SN, Nandhini Devi GSD, Immaculate Nancy Rebecca A, Kalaichelvan PT (2012) Production and optimization of feather protein hydrolysate from Bacillus sp. MPTK6 and its antioxidant potential. Middle-East J Sci Res 11:900-907

Kurbanoglu EB, Kurbanoglu NI (2007) Ram horn hydrolysate as enhancer of xanthan production in batch culture of Xanthomonas campestris EBK-4 isolate. Process Biochem 42:1146-1149. https://doi.org/10.1016/j.procbio.2007.04.010

Laemmli UK (1970) Cleavage of structural proteins during the assembly of the head of bacteriophage $\mathrm{T}_{4}$. Nature 227:680-685. https:// doi.org/10.1038/227680a0

Liu JK, Waibel PE, Noll SL (1989) Nutritional evaluation of blood meal and feather meal for turkeys. Poult Sci 68:1513-1518. https://doi.org/10.3382/ps.0681513

Mokrejs P, Svoboda P, Hrncirik J, Janacova D, Vasek V (2011) Processing poultry feathers into keratin hydrolysate through alkalineenzymatic hydrolysis. Waste Manag Res 29(3):260-267. https:// doi.org/10.1177/0734242X10370378

Nagai Y, Nishikawa T (1970) Alkali solubilization of chicken feather keratin. Agric Biol Chem 3:16-22. https://doi.org/10.1080/00021 369.1970.10859572

Nakamura A, Arimoto M, Takeuchi K, Fujii T (2002) A rapid extraction procedure of human hair proteins and identification of phosphorylated species. Biol Pharm Bull 25:569-572. https://doi.org/ 10.1248/bpb.25.569
Nomura Y, Aihara M, Nakajima D, Kenjou S, Tsukuda M, Tsuda Y (2007) Process for producing solubilized keratin US Patent 2007/0207111 A1

PlasticsEurope. Association of Plastic Manufacturers. Plastics - the Facts 2020. An analysis of European plastics production, demand, and waste data, https://www.plasticseurope.org/en/resources/market-data. Accessed 23 May 2021

Reddy N, Chen L, Yang Y (2013) Biothermoplastics from hydrolyzed and citric acid crosslinked chicken feathers. Mater Sci Eng C 33:1203-1208. https://doi.org/10.1016/j.msec.2012.12.011

Saravanan K, Dhurai B (2012) Exploration on amino acid content and morphological structure in chicken feather fiber. J Text Apparel Technol Manag 7:1-6

Schrooyen PMM, Dijkstra PJ, Oberthü RG, Bantjes A, Feijen J (2000) Partially carboxymethylated feather keratins. 1. Properties in aqueous systems. J Agric Food Chem 48:4326-4334. https://doi. org/10.1021/jf9913155

Schrooyen PMM, Dijkstra PJ, Oberthür RC, Bantjes A, Feijen J (2001) Partially carboxymethylated feather keratins. 2. Thermal and mechanical properties of films. J Agric Food Chem 49:221-230. https://doi.org/10.1021/jf0004154

Singh V, Wang S, Ng KW (2017) Keratin as a biomaterial. In: Ducheyne P, Healy K, Hutmacher DW, Grainger DW, Kirkpartrick J (eds) Comperhensive biomaterials II. Biologically inspired and biomolecular materials. Elsevier, Amsterdam, pp 542-557

Sinkiewicz I, Śliwińska A, Staroszczyk H, Kołodziejska I (2017) Alternative methods of preparation of soluble keratin from chicken feathers. Waste Biomass Valori 8:1043-1048. https://doi.org/10. 1007/s12649-016-9678-y

Song NB, Jo WS, Song HY, Chung KS, Won M, Song KB (2013) Effects of plasticizers and nano-clay content on the physical properties of chicken feather protein composite films. Food Hydrocoll 31:40-345. https://doi.org/10.1016/j.foodhyd.2012.11.024

Tsuda Y, Nomura Y (2014) Properties of alkaline-hydrolyzed waterfowl feather keratin. Anim Sci J 85:180-185. https://doi.org/10. 1111/asj.12093

USDA (2016) Livestock and poultry: World markets and trade, 9, https://usda.library.cornell.edu/concern/publications. Accessed 23 May 2021

Vineis C, Cruz Maya I, Mowafi S, Varesano A, Sánchez Ramírez DO, Abou Taleb M, Tonetti C, Guarino V, El-Sayed H (2021) Synergistic effect of sericin and keratin in gelatin based nanofibers for in vitro applications. Int J Biol Macromol 190:375-281. https:// doi.org/10.1016/j.ijbiomac.2021.09.007

Vethaak AD, Leslie HA (2016) Plastic debris is a human health issue. Environ Sci Technol 50:6825-6826. https://doi.org/10.1021/acs. est.6b02569

Wang B, Yang W, McKittrick J, Meyers MA (2016a) Keratin: structure, mechanical properties, occurrence in biological organisms, and efforts at bioinspiration. Prog Mater Sci 76:229-318. https://doi. org/10.1016/j.pmatsci.2015.06.001

Wang Y, Zhang W, Yuan J, Shen J (2016b) Differences in cytocompatibility between collagen, gelatin and keratin. Mater Sci Eng C 59:30-34. https://doi.org/10.1016/j.msec.2015.09.093

de Winter JCF, Dodou D (2017) Experimental design . In: de Winter JCF, Dodou D (eds) Human subject research for engineers: a practical guide. Springer Verlag, Cham, pp. 17-39

Publisher's note Springer Nature remains neutral with regard to jurisdictional claims in published maps and institutional affiliations. 